\title{
Anscombe and Geach on Mind and Soul
}

\author{
John Haldane
}

\section{Abstract}

Anscombe and Geach were among the most interesting philosophers to have come out of Oxford in the twentieth century. Even before they encountered Wittgenstein they had begun to distinguish themselves from their contemporaries, and in the course of their work they moved between highly abstract and often technical issues and themes familiar to non-academics, the latter aptly illustrated by the title of Geach's first collection of essays God and the Soul, and by that of Anscombe's analysis of human sexual acts "Contraception and Chastity". ${ }^{1}$ I consider their early work together and illustrate its influence on later writings by each. I then examine the ideas and arguments advanced in those writings in so far as they bear upon the issue of materialism, and the question of the existence and nature of the soul. Finally, I respond to their somewhat skeptical arguments, though conclude that there is also reason to acknowledge the propriety of what I will term 'spiritual agnosticism'.

\footnotetext{
${ }^{1}$ Peter Geach, God and the Soul (London: Routledge Kegan \& Paul, 1969); Elizabeth Anscombe "Contraception and Chastity" in Mary Geach \& Luke Gormally eds, Faith in a Hard Ground: Essays on Religion, Philosophy and Ethics by G.E.M. Anscombe (Exeter: ImprintAcademic, 2008): 170-91.
} 
Reflecting on his intellectual life and his relationship as a philosopher with Elizabeth Anscombe. Peter Geach observed:

"Although we have both followed a philosophical career, and have sometimes formally collaborated and often critically read one another's works, we think about different though overlapping topics, and in a noticeably different style; and either of us, when questioned about the thought of the other, will often not know the right answer. I am surprised that people find this surprising" 2

Elizabeth Anscombe (1919-2001) and Peter Geach (1916-2013) met in Oxford in 1938 and married three years later on Boxing Day 1941 at Brompton Oratory in London. They retired from full time professorial positions in the 1980s: he from Leeds in 1981, she from Cambridge in 1986. Thereafter they continued to read papers and to publish for a decade or more. We may say, therefore, that they shared lives as productive philosophers for over half a century; they also occasionally referred explicitly to one another in print mostly citing particular items. In part this essay addresses three biographical-cum-interpretative questions: to what extent did they work together? what themes emerge from any significant collaboration? and is their mutual influence evident in their individual writings? I am also concerned, however, with two philosophical issues: first, what is the nature of their resistance to the idea of a surviving subsistent immaterial soul? and second, how might one respond to the objections they raise?

\section{II}

\footnotetext{
${ }^{2}$ Peter Geach “Intellectual Autobiography” in Harry A. Lewis ed. Peter Geach: Philosophical
} Encounters, (Dordrecht: Kluwer, 1991): 10. 
So far as "working together" might mean contributing to a joint project, which is what, I think, Geach had in mind in speaking of having "formally collaborated", the answer to the question "to what extent did they work together?" is very little. It is worth mentioning at the outset, however, that in the four to six year period between them meeting in Oxford and marrying, and Anscombe later beginning to attend Wittgenstein's classes as a post-graduate in Cambridge first in 1941/2 and then when he resumed lecturing in 1944, Geach acted as something of a philosophy 'tutor' to her. In his "Philosophical Autobiography", quoted from above, he writes:

Elizabeth had a lot of philosophical teaching from me. I could see that she was good at the subject, but her real development was to come only under the powerful stimulus of Wittgenstein's lectures and her personal conversations with him. Naturally she then moved away from my tutelage; I am afraid that I resented that, but I could recognize this feeling as base and irrational, and soon overcame it. ${ }^{3}$

Geach had graduated from Balliol with a First in literae humaniores in 1938 and been awarded a Gladstone Research Studentship (at Gladstone's Library at Hawarden in North Wales) for which he chose the topic of John McTaggart's idealist metaphysics. The subject was one about which he was already quite knowledgeable having been directed to read McTaggart's Some Dogmas of Religion at about the age of twelve by his father George Geach who had been a student with C.D. Broad and Wittgenstein at Trinity College Cambridge, studying there with G.E. Moore, Bertrand Russell, John Neville Keynes and McTaggart himself.

Geach Senior had come back to England having been a professor of philosophy in the Indian Educational Service, but then being unable to secure a professorship in England he

\footnotetext{
${ }^{3}$ Ibid. 11 .
} 
devoted himself to teaching his son from Keynes's Formal Logic, proceeding to Principia Mathematica, and while the younger Geach was still at school set the foundation for him to make a serious study of McTaggart's The Nature of Existence. Two points arising from this precocious background are relevant to his influence on Anscombe and may bear upon their most nearly joint academic project which I will describe in detail in a moment. First, when they met and took up with one another, and during the period of her undergraduate studies also in Lit. Hum., Geach was already well-read, publicly acknowledged to be exceptionally gifted, and desirous of sharing the fruits of his studies. Second, his familiarity with and liking for McTaggart's spiritualist idealism, which maintained the reality of souls in loving communion with one another, made him unresponsive to the Cartesian problems of egocentrism and other minds, and ripe for the idea, which he and Anscombe would later get from Wittgenstein, that participation in shared forms of life is necessary for human intellectual activity, and that on this account there is no question of doubting that others think, or indeed in many cases what they think, given that language manifests thought and that meaning is public.

Two books are attributed to Anscombe and Geach jointly. First, Descartes Philosophical Writings ${ }^{4}$ in which they translated and edited selected texts: the Meditations, most of the Discourse on Method, parts of the Principles, extracts from Rules for the Direction of the Mind and Notes on a Certain Program, and a few other items. Second, Three Philosophers ${ }^{5}$ consisting of three chapters on Aristotle, Aquinas and Frege, respectively.

\footnotetext{
${ }^{4}$ G.E.M. Anscombe and P.T. Geach, Descartes Philosophical Writings (Edinburgh: Thomas Nelson, 1954).

${ }^{5}$ G.E.M. Anscombe and P.T. Geach, Three Philosophers (Oxford: Blackwell, 1961).
} 
These two works are different in composition. The first was a collaborative effort in which they discussed translations, selections and a note to readers, though most of the work was done by Geach. ${ }^{6}$ The volume carries an introduction by the historian and philosopher of modern science Alexander Koyre which is celebratory of Descartes' work but makes no reference to the translation. Anscombe and Geach themselves present only a 'Translators' Note' yet this is of some significance for it explains a rendering decision that represents a particular interpretation of Descartes' account of the nature of mind, an interpretation that would feature prominently in later writings by each ${ }^{7}$ and which influenced others in thinking about Cartesian philosophy of mind. $^{8}$

${ }^{6}$ See Anthony Kenny Peter Geach “Peter Thomas Geach (1916-2014)” Biographical Memoirs of Fellows of the British Academy, XIV, (London: British Academy, 2015) 185-203; 191.

${ }^{7}$ See Anscombe, "Events in the Mind" a paper dating from 1963 but first published in 1981 and “The First Person" (1975) in which she attacks Descartes' argument for dualism, both essays appear in Metaphysics and the Philosophy of Mind. The Collected Philosophical Papers of G.E.M. Anscombe, vol. II (Oxford: Blackwell, 1981) 21-36 and 56-63. In a rare reference to the Descartes volume Anscombe writes in footnote 1 of the latter essay that "Principles of Philosophy, I, LX contains Descartes' best statement [of his argument]" and then quotes the passage from her and Geach's edition of Descartes Philosophical Writings, Ibid 21. For Geach see Mental Acts: Their Content and their objects (London: Routledge \& Kegan Paul, 1957) section 26.

${ }^{8}$ As indicative see Anthony Kenny, Descartes, A Study of his Philosophy (New York: Random House, 1968) and Saul Kripke, “The First Person" in Saul A. Kripke, Philosophical Troubles, Collected Papers, Volume I (New York: Oxford University Press, 2011) Ch. 10. 
Up to that point, and until the publication in 1985 of the Cambridge University Press two volume edition of The Philosophical Writings of Descartes translated by John Cottingham, Robert Stoothoff and Dugald Murdoch, the standard English rendering of Descartes' texts was the Elizabeth Haldane and G.R.T. Ross translation The Philosophical Works of Descartes (1911, also published by Cambridge) which does not introduce interpretative emphases into the translated text. Anscombe and Geach explain the significance of their translation decision as follows:

"The most important problem of a Descartes translation is the rendering of the verbs cogitare and penser and their derivatives. Since Locke, the traditional English renderings have been the verb think and the noun thought. We have decided to abandon this tradition, which seems to us to run the risk of seriously misrepresenting what Descartes says. ... Descartes himself defines the words as applying not only to intellectual processes but also to acts of will, passions, mental images, and even sensations. ... The words think and thought will sometimes do ... We have, however, often found it advisable to use more general terms, such as the noun and verb experience and the adjective conscious; we have fairly consistently used conscious being as a rendering of res cogitans." 9

The point is evidently connected with the fact that Aristotle, his medieval followers and later scholastic-trained philosophers, including Descartes' own Jesuit teachers at La Fleche, distinguished between sensory experience and thought, attributing the former to the sense powers, and the latter to an intellectual power which, together with the will, comprises the rational mind. Descartes departs from this tradition by bundling of all psychological states into a

\footnotetext{
${ }^{9}$ Op. cit. xlvii-xlviii.
} 
single broad category 'mind' (mens) and in treating consciousness as being the criterion of inclusion within this. Anscombe and Geach do not include the Second Set of Replies to the Meditations where Descartes says as much but they do begin the selection from Principia Philosophiae with section 9 where (in their translation) he writes:

"By the term conscious experience (cogitationis) I understand everything that takes place within ourselves so that we are aware of it (nobis cosciis), in so far as it is an object of our awareness (conscientia). And so not only acts of understanding, will and imagination, but even sensations, are here taken as experience (cogitare)." 10

It is worth emphasizing how innovative was Descartes' use of cogitatio or pensée to cover any kind of mental item. His contemporary readers initially supposed that he meant acts of judgement, and so objected that in characterising human psychology in terms of these he was seemingly omitting much else. One such was le Père Mersenne to whom Descartes replies writing "You argue that if the nature of man is solely to think, then he has no will. I do not see that this follows; for willing, understanding, imagining, and sensing and so on are just different ways of thinking, and all belong to the soul."11

There is a further, and arguably more important, feature of their translation that Anscombe and Geach do not mention but which is also part of their interpretation of the distinctiveness of Descartes position. It concerns the object of self-awareness as rendered

\footnotetext{
${ }^{10}$ Ibid. 183.

11 "Letter to Mersenne End of May 1637" in John Cottingham, Robert Stoothoff, Dugald Murdoch and Anthony Kenny trans. The Philosophical Writings of Descartes: Volume 3, The Correspondence (Cambridge: Cambridge University Press, 1991) 56.
} 
through the first person reflexive pronoun "I". In their translation of Meditation II which contains Descartes famous argument that his conscious/thinking self (ego ipse cogitans) is distinct from his body, they italicize $I$ or put it into single inverted commas: ' $I$ '. The first measure might be read simply as giving emphasis but both are intended to capture a kind of usage that they are thereby attributing to Descartes. One might wonder whether this is a question-begging intrusion, for in the original text when he writes of wanting to know what it is of which he is conscious when he is aware that he exists, Descartes does not seem to mark out ego in any distinctive way (writing "Novi me existere; quaero, quis sim ego, ille, quem novi"). In fact, however, there is a peculiarity here, for he applies the demonstrative 'that' (ille) to the first person pronoun (ego) thereby putting the latter into the category of a generic term just as much would the use of a definite or indefinite article.

Since Anscombe and Geach provide no philosophical commentary, and do not advert to the treatment of ' $I$ ' in the prefatory note, my attribution of an interpretative purpose might seem conjectural. In fact, however, it became an important feature of their criticism of Descartes' argument for mind/body dualism that they read him as introducing in the Meditations a special use of 'I' in the reporting of thoughts and utterances, and as presenting an associated special mode of reflection. This diagnosis is a feature of Anscombe's famous essay "The First Person" where she argues that Descartes' proof of the non-identity of himself with the human being involves a special indirect reflexive use of 'myself' which is parasitic upon an understanding of a use of 'I' that is presupposed in Descartes's self-addressed reflections. ${ }^{12}$

Anscombe holds that in the context of these reflections, which include doubts as to whether subjective experience presents any material existent, this involves an illegitimate

\footnotetext{
12 "The First Person" op. cit..
} 
transposition of an ordinary reflexive indicator into the category of a referring expression, which because of seeming immunity to error through misidentification calls for a special kind of referent distinct from Descartes the man. She writes

"[If the referent of 'I' is not this body] Nothing but a Cartesian Ego will serve. ... Thus we discover that if "I" is a referring expression then Descartes was right about what the referent was ..."

Then later she writes

"With that thought: 'The I was subject, not object, and hence invisible', we have an example of language itself being as it were possessed of an imagination, forcing its image upon us.

The dispute is self-perpetuating, endless, irresoluble, so long as we adhere to the initial assumption, made so far by all the parties to it: that "I" is a referring expression. ... And this is the solution: "I" is neither a name nor another kind of expression whose logical role is to make reference, at all." 13 Anscombe's conclusion about "I" not being a referring expression has been widely rejected and even treated as evidently absurd, ${ }^{14}$ but it is important in evaluating it to take full account of the Cartesian context which provides the setting, and to note that the use of "I" with which she was concerned was one taken to be such that it could not fail of reference. Part of the widespread dismissal of her case is also attributable, however, to her characteristically dense and

${ }^{13}$ Ibid. 31-32.

${ }^{14}$ One salient consideration is that any inference in which ' $I$ ' is treated referentially is valid, e.g. "I have a headache" entails "someone has a headache"; "neither I nor anyone else was present" entails "no-one was present" and so on. 
non-linear style of argumentation. It is valuable, therefore, to compare her criticisms with the briefer, clearer and more engagingly presented reasoning to a similar conclusion given by Peter Geach in Mental Acts and again in "Reincarnation". 15 The first was published in 1957 (the same year as Anscombe published Intention) and the second in 1969 in God and the Soul, but, as the preface to the latter reports, Mental Acts borrowed material from an earlier version of 'Reincarnation', so we may suppose that the relevant part was written quite close to the period of the Descartes' translations. Here then is a passage from "Reincarnation" which anticipates the publication of Anscombe's “First Person" argumentation by twenty years:

"If I enunciate propositions containing the word 'I' to hearers or readers, they will be given certain information, true or false, about the speaker or writer: they will be truly informed if and only if the corresponding proposition is true that they would enunciate using 'Peter Geach' where I use 'I' and making the requisite grammatical changes. ...

The only interpretation of 'I' for which [empirical - my term] first-person propositions would not be straightforwardly [confirmable - my insertion] or refutable is a certain solioquistic use of ' $\mathrm{I}$ '. By way of illustrating this, consider a Descartes brooding over his German stove and saying., 'I'm getting into a frightful puzzle - but what then is this "I" that is puzzled? ... ... The use of 'I' here is essentially soliloquistic; the idea is that each man who has mastered the use of 'I' could in solitude use these lines of argument to convince himself.

${ }^{15}$ See Mental Acts, section 26, especially 118-120; and 'Reincarnation' in God and the Soul, 116, especially 6-9. 
... But what is it that is indubitable? What are the soliloquistic utterances 'I am in horrible pain' and 'I am frightfully puzzled' supposed to supply over and above the soliloquistic utterances 'This pain is horrible' and 'This is frightfully puzzling'? ...

... It appears to me that this use of 'I' in soliloquy is a degenerate use, and there is no question of it referring to anything." 16

What emerges from the Descartes translations and the writings that follow and implicitly refer back to it ${ }^{17}$ is a shared view of Descartes' revolution: in effect introducing what proved to be a compelling conception of the human person and of the primary tasks of philosophy, viz. relating the conscious immaterial self, epistemologically and ontologically, to non-mental reality. So far as evaluation of Descartes' philosophy is concerned they might be described as holding that he was a genuinely creative but misdirected thinker (an opinion they also shared regarding David Hume). In particular, in their estimate, Descartes re-oriented philosophical thinking about mind and knowledge by introducing a particular form of seemingly self-directed thought and by extending the notion of thought itself from a restricted range of intellectual operations to consciousness in general.

The second book bearing their names as authors - Three Philosophers - does not assign chapters to writers individually and this might lead some to suppose they were co-authored. They were not. Anscombe wrote the Aristotle chapter and Geach those on Aquinas and Frege. This is

\footnotetext{
${ }^{16}$ Ibid. 6-7.

${ }^{17}$ Geach in "Reincarnation" 8, writes: "was it, perhaps, by a Freudian self-betrayal that Descartes wrote in his private notebook 'lavartus prodeo', 'I come forward in a mask'?" here recalling the opening paragraph of the first selection in Descartes Philosophical Writings, 3.
} 
clear enough from the prose styles and preoccupations but it is testified to by the fact that the Aristotle chapter evidently derives from Anscombe's 1952 Joint Session paper "The Principle of Individuation", ${ }^{18}$ while the Aquinas one reproduces elements from Geach's "Form and Existence", ${ }^{19}$ and the Frege one reiterates points made in several of his Philosophical Review articles from the 1950s (later gathered in Logic Matters ${ }^{20}$ ).

In summary, these chapters argue 1) that the core of Aristotle's philosophy is his metaphysics, more particularly his theory of substance; 2) that Aquinas was wide-ranging, prudent and insightful, especially with regard to the nature of causation and cognition, with again metaphysics being the key to understanding his ideas; and 3) that Frege's theory of functions serves to illuminate both semantics and Aquinas's account of essence and existence. The last point is not presented in the Frege chapter but in the Aquinas one, while the Aristotle chapter refers us to that on Aquinas for a development of the idea proposed in the De Anima that cognition involves receiving the form of the object into the cognitive faculty as a determining structure: what in the thing was a substantial or accidental nature is in the sense or in the intellect a perceptual or conceptual structure.

While there is some acknowledgement of the presence of other chapters but there is no special effort to relate them. Here the two authors were pursuing their individual enthusiasms and it is clear from later writings that in general either tact was exercised in not taking exception to points made by the other, or else it was only on later reflection that differences came to be

${ }^{18}$ Reprinted in From Parmenides to Wittgenstein. The Collected Philosophical Papers of G.E.M. Anscombe, vol. I (Oxford: Blackwell, 1981) 57-65.

${ }^{19}$ God and the Soul, 42-64.

${ }^{20}$ Peter Geach, Logic Matters (Oxford: Blackwell, 1972). 
acknowledged. One example may be mentioned which is also relevant to points made below. The theory of thought as sharing the same form (in esse intentionale) as its worldly correlate (in esse naturale) is expounded approvingly by Geach in "Form and Existence" and later defended in the course of replying to an essay by Anthony Kenny. ${ }^{21}$ Anscombe, however, in a paper which does not refer to Geach entitled "Thought and the Existence of Objects" (of unknown date and only recently published) claimed to be able to make little of this idea, ${ }^{22}$ and elsewhere, as will be seen, she seems close to actual criticism.

In that connection it should also be noted that she was a more spontaneous, less systematic and less literary writer than he. Both were highly creative, introducing a number of important ideas into contemporary philosophy several of which are referred to by the expressions they gave them such as, in Anscombe's case 'brute fact', 'consequentialism', 'non-observational knowledge', and 'under a description', and in Geach's 'Cambridge change', 'intentional identity', 'personal vs impersonal reference', and 'relative identity'. But whereas Geach's work appears well-composed and well-stocked with philosophical, theological, historical and literary references, Anscombe's writings usually give the sense of starting afresh each time in response to some newly discovered, or freshly returned to puzzle, not writing to a plan but setting down the movement of thought and only occasionally referring to contemporary philosophers, even more rarely quoting particular texts. These differences contribute to the common experience of his work as being a delight to read and of hers as inducing the sense of being dragged through a

${ }^{21}$ See Anthony Kenny "Form, Existence and Essence" and Peter Geach reply in Peter Geach: Philosophical Encounters, 65-75 and 256-7.

22 "Thought and the Existence of Objects" in Mary Geach and Luke Gormally eds. Logic, Truth and Meaning, Writings by G.E.M. Anscombe (Exter: ImprintAcademic, 2015) 198-205. 
dense forest by a powerful solitary animal as it simultaneously evades predators and pursues prey. In the passage from his "Philosophical Autobiography" that heads this essay Geach writes: "we think about different though overlapping topics, and in a noticeably different style". I have said what part of that difference consists in, but there is something else, I suggest, that explains this: Geach had the thinking and writing manner of a literary don even when he was young; Anscombe had those of a spirited student even when she was old. His prose style is continuous with that of Bunyan, Johnson and Chesterton while hers is often Socratic, sometimes colloquial, and occasionally inclines to the satirical modes of Juvenal and Swift. It is tempting to add that hers also reflects the vocabulary and style of Wittgenstein as it appears in the Philosophical Investigations, but while her thought and mode of expression certainly were influenced by Wittgenstein it also has to be taken account of that the translation is by Anscombe and no doubt something of her style influenced that of the published text.

Before proceeding to the next section in which I consider what Anscombe and Geach singly have to say on their own accounts about the nature of mind and soul I want to suggest that these early books are very significant in revealing something of their approach to philosophy and in shaping the concerns of their subsequent work.

First there is the obvious fact of them engaging with historical figures: Aristotle, Aquinas, Descartes and Frege but in ways that bring them into relation with contemporary philosophy, even though the latter is often not adverted to. Anscombe's first three papers in professional academic journal were "The Reality of the Past" (1950), "The Principle of Individuation" (1953), and “Aristotle and Sea Battle" (1956); ${ }^{23}$ Geach's (other than

${ }^{23}$ The first is reprinted in Metaphysics and the Philosophy of Mind. The Collected Philosophical Papers of G.E.M. Anscombe, vol. II (Oxford: Blackwell, 1981) 104-19, and the second and third 
logical/semantic pieces) were "Form and Existence" (1955), "Good and Evil" (1956) and "The Third Man Again" (1956) ${ }^{24}$; Aristotle being drawn on directly in the first, second, third and fifth, Aquinas in the fourth, and Plato in the sixth. This engagement with the past is certainly not antiquarian, nor just an artifact of classical education. Rather Anscombe and Geach responded to figures who appeared to them as great philosophers, rather than to contemporaries who seemed, like themselves, gifted students and teachers of an academic discipline. Second, however, is the fact that they were engaged by large issues: metaphysics, thought, language and reality, human nature, and the debate between materialism and spiritualism (the latter in a non-occultist sense that will be clearer shortly). It is to that last theme that I now turn.

III

Anscombe and Geach both made important contributions to philosophy of psychology: she through Intention $(1957)^{25}$ and subsequent writings on action and practical reasoning; he through Mental Acts (1957) and a number of essays related to the theme of his third and unpublished series of Stanton Lectures (entitled Freedom and Prediction). ${ }^{26}$ Neither, however,

in From Parmenides to Wittgenstein. The Collected Philosophical Papers of G.E.M.

Anscombe, vol. I (Oxford: Blackwell, 1981) 57-65 and 44-55, respectively.

24 “Good and Evil” Analysis 17 (1956): 33-42; “The Third Man Again”, Philosophical Review 65 (1956): 72-82.

${ }^{25}$ G.E.M. Anscombe, Intention (Oxford: Blackwell, 1957).

${ }^{26}$ Geach proclaimed himself unsatisfied with what he had managed to produce but parts of the series were drawn upon in published essays such as that contributed to a volume on Anscombe; see Peter Geach, "Intention, Freedom and Predictability" in Roger Teichmann ed. Logic, Cause 
gave a great deal of time to the 'mind-body problem' and it is hard to construct definite general theories from their writings. Part of the explanation for this is their shared belief that the usual ways of formulating mind-body questions involve the kind of Cartesian distinctions and inferences they had come to think confused and fallacious. More positively they subscribed to the Aristotelian view that the soul is the principle of life, organisation and activity of the living human body, and that 'mind' is not a thing (material or immaterial) but a set of capacities for thought of various kinds. Even so they believed that the exercise of this capacity, while it might be expressed in bodily activity, is not itself a material process and they thought that this conclusion could be argued for. I will consider some of those arguments shortly but I want to anticipate their shared conjecture - held very firmly by Anscombe and somewhat less firmly by Geach - namely that little, if any, natural sense can be made of the idea of a subsistent immaterial soul. Again they thought that this skeptical conclusion can be argued for, and I will also summarise those arguments before responding to them on behalf of the claim which they both knew that Aquinas, for whom they had great respect, advanced: that the existence of an immaterial subject follows from the fact of immaterial acts, and that this subject is separable from the human body.

In Mental Acts Geach first argues against the view of Ryle that ascriptions of psychological events and activities are equivalent to semi-hypothetical statements about and Action: Essays in Honour of Elizabeth Anscombe (Cambridge: Cambridge University Press, 20) $73-82$. 
behavior. ${ }^{27}$ His objections include the observation that the attempt to distinguish between two individuals' different mental states exhaustively in terms of different behavioural dispositions gets things back to front. We explain differences in behavior by reference in part, but ineliminably, to mental acts and not by hypothetical differences in the agents concerned. Furthermore, where two subjects did not differ in behavior it is intelligible to suppose that they may yet have been in different mental states without having any view regarding the truth of different counterfactuals about what each would have done if things that did not happen had occurred. On this basis Geach maintains that at least some psychological ascriptions, those attributing mental acts and events, are categorical and not hypothetical in character.

That fact, however, would be compatible with the events themselves being physical, as in type or token versions of materialism, but Geach rejects this possibility by reference to aspects of thinking and to the character of descriptions of human thought, language and action. The latter argument (which is also to be found in passing in Anscombe ${ }^{28}$ ) is first given in "Faith" chapter 2 two of The Virtues where Geach discuses the question of how original sin might be inherited and observes that

"[t]he modes of description needed for human intellectual activities, language and institutions are logically different from those that will serve to describe the facts

${ }^{27}$ Both Geach and Anscombe take exception to, and show errors in the attribution of similar views to Wittgenstein. For Geach see Mental Acts, 2-4. For Anscombe "Analytical Philosophy and the Spirituality of Man" discussed below.

${ }^{28}$ See "On Wisdom" in Mary Geach and Luke Gormally eds. Faith in a Hard Ground: Essays on Religion, Philosophy and Ethics by G.E.M. Anscombe (Exeter: Imprint Academic, 2008) in 258-66. 
and laws of sub-human nature. If so, then no logic can derive from the facts and laws of sub human nature an explanation of human nature.

[Later he continues]. "I cannot here develop the logical difference I have alluded to; Quine has anyhow done the work for me in Word and Object and other writings. He insists that here is no logical bridge from the propositions of natural science to the language involving indirect speech constructions that we naturally use to describe our own and our fellows' attitudes and meanings". ${ }^{29}$

The logical difference in question is between descriptions that are and those that are not intensional, in the former case (among other features) resisting substitution of co-extensive expressions salva veritate. "Edinburgh" and "The capital of Scotland" are co-designating such that "Edinburgh has a population of more than 250,000" is true if and only if "The capital of Scotland has a population of fewer than 250,000" but "John believes that Edinburgh has a population of fewer than 250,000 " may be true while "John believes that the capital of Scotland" has a population of fewer than 250,000 " may be false - likewise for orationes obliquae such as "John says that ..." etc.

While I am sympathetic to arguing from the intensionality of descriptions of human activity to the falsity of materialism ${ }^{30}$ this style of argument is open to two kinds of objections. First, that implied by Quine's strictures against "intensional idiom" viz. that it is a façon de parler and should not be treated as factive. Second, that the logical non-derivability, or

${ }^{29}$ Geach, The Virtues (Cambridge: Cambridge University Press, 1977): 26-7.

${ }^{30}$ For an extended argument in this vein see John Haldane, "Naturalism and the Problem of Intentionality" Inquiry, 32 (1989): 305-22, and "A Return to Form in the Philosophy of Mind" Ratio, 11 (1998): 253-277. 
reducibility, of intensional descriptions and explanations to extensional ones is a linguistic or conceptual phenomenon and does not settle the question of the ontological character of thoughts, utterances and actions. More precisely they could be physical even if certain ways of specifying them are non-scientific or otherwise do not imply their materiality.

This is not the occasion to engage those responses ${ }^{31}$ but in any case Geach has a more directly ontological argument against materialism. This is presented in his essay "What Do We Think With?” and relevantly it draws upon a distinction made by Anscombe in her essay “On Brute Facts", ${ }^{32}$ There Anscombe distinguished between levels of description illustrated by the fact that 1) in a certain context bringing vegetables to one's house might be 2) supplying foodstuffs, which given further contextual features might amount to 3) fulfilling a contract. She describes the relationship between the facts described in 1) 2) and 3) as one of "brute relativity": 1) is brute relative to 2), 2 brute relative to 3). Geach adopts this logical analysis re-terming it one of relative basicness. His argument against materialism is then based on the following premises:

I. Thinking is an activity.

${ }^{31}$ See Haldane ibid., and "Folk Psychology and the Explanation of Human Behaviour" Proceedings of the Aristotelian Society, Supplementary Volume Vol. 62 (1988): 223-254, also Barry Stroud, "Quine on Exile and Acquiesence” in Stroud, Meaning, Understanding and Practice (Oxford: OUP, 2000): 151-69.

${ }^{32}$ The Collected Philosophical Papers of G.E.M. Anscombe: Ethics, Religion, and Politics (Oxford: Blackwell, 1981): 22-5. 
II. Thinking is a basic activity (there is nothing else more basic the occurrence of which in a context constitutes thinking).

III. The activity of thinking does not have the kinds of time-relations that physical processes have.

Given the identity of indiscernibles or its contrapositive which Geach following McTaggart termed "the diversity of dissimilars", ${ }^{33}$ it follows from III that thinking is not a physical process. This is an interesting argument and it is surprising that until recently it barely received any attention beyond mention in reviews of God and the Soul in which it was published. ${ }^{34}$ Its first premise follows upon what Geach had argued in Mental Acts and is independently plausible. The third premise is the most complex in its grounds, and it could perhaps be accepted by a non-reductive token-physicalist who might distinguish relations between events qua physical and qua elements in phenomenal consciousness. It is, however, the second that a defender of physicalism is most likely to head for and about Geach himself writes: "This, I think, is the point at which my argument should be most closely scrutinized. But so far as I can see, thinking is a basic activity". 35 His judgement might be further supported by reflecting on the hyper-intensionality of thought, though here I am not concerned to defend

${ }^{33}$ See Peter Geach, Truth, Love and Immortality: An Introduction to McTaggart's Philosophy (London: Hutchinson, 1979) 51.

${ }^{34}$ Recent discussion is more concerned premise III considered not as contradicting materialism but as concerning the character of consciousness. See Matthew Soteriou The Mind's

Construction: The Ontology of Mind and Mental Action (Oxford: OUP, 2013) chapter 2, and Elijah Chudnoff, Cognitive Phenomenology (London: Routledge, 2015): 90-99.

${ }^{35}$ Op. cit., 37. 
Geach's argument but to focus on its conclusion. He writes "Materialism then is false but it does not follow that immaterialism is true". These contraries, as he conceives them, agree that a person thinks with a part of themselves; what they disagree over is whether that part is a material or an immaterial one. Regarding the latter thesis Geach writes:

"It is a savage superstition to suppose that a man consists of two pieces, body and soul, which come apart at death; the superstition is not mended but rather aggravated by conceptual confusion, if the soul piece is supposed to be immaterial. ... In truth a man is a sort of body, not a body plus an immaterial somewhat; for a man is an animal, and an animal is one kind of living body; and thinking is a vital activity of a man, not of any part of him, material or immaterial. The only tenable conception of the soul is the Aristotelian conception of the soul as the form, or actual organization, of the living body; and thus you may say that a man thinks with his soul, if you mean positively that thinking is a vital activity of a living human being, and negatively that thinking is not performed by any bodily organ"36

In light of this and of remarks made in an ancestor of the time-relations argument in Mental Acts, where there is no mention of an anti-materialist conclusion, ${ }^{37}$ the paragraph

\footnotetext{
${ }^{36}$ Ibid. 38.

${ }^{37}$ He writes: "What I have just said about the 'loose' relation of judgements to physical time is a logical point about applying time-specifications in our discourse about judgements; it does not imply e.g. that judgements are really performed in a super-physical realm. ... and for judgements to be tied loosely to physical time is still for them to be tied." Mental Acts 106.
} 
immediately succeeding the one just quoted and what follows it, may come as something of a surprise.

"In our present experience we encounter thought as an activity or organisms. But since thought is in principle not locatable in the physical time continuum, as the vegetative, and I think also the sensitive, activities of organism are, there is a logically open possibility that thought should occur independently, not as the activity of a living organism." 38

Then later, he writes:

And some continuing disembodied thought might have such connexion with the thoughts I have as a living man as to constitute my survival as a 'separated soul'. To be sure, such survival must sound a meager and unsatisfying thing; particularly if it is the case, as I should hold, tha there is no question of sensations and warm feelings and mental images existing apart from a living organism. But I do not want the prospect to be anything but bleak; I am of the mind of Aquinas about the survival of 'separated souls', when he says in his commentary on I Corinthians that my soul is not I, and if only my soul is saved then I am not saved and nor is any man." 39

A fairly clear tension exists between the paragraph beginning "It is a savage superstition to suppose that a man consists of two pieces, body and soul, which come apart at death" and that occurring on the facing page regarding "my survival as a 'separated soul'". The explanation of this, I suggest, is that Geach is indeed conflicted

${ }^{38}$ Op. cit. 38

${ }^{39}$ Ibid 39-40. 
trying to hold on with one hand to a Wittgensteinean view and with another to a Thomistic one.

IV

I will come to Aquinas's position in due course but next I turn to consider Anscombe's discussions of associated issues. Here, additional to items previously cited, four essays and an interview are relevant: a) “The Immortality of the Soul” (1950s), b) "Analytical Philosophy and the Spirituality of Man” (1979), c) “The Causation of Action” (1983) d) "Has Mankind One Soul?" (1985) and d) “The Existence of the Soul” (1990s) $)^{40}$

In the third of these Anscombe is concerned to reject (as she had done in Intention $\$ \S 9$ 11) an approach to the nature and explanation of action according to which actions are events caused by reasons typically conceived of as belief/desire pairings. In "The Causation of Action" she presses the point that this way of thinking, conjoined with natural assumptions about the causation of bodily movement, leads to the identification of the having and mental expression of reasons with states of the brain. Against this she argues that the content of beliefs is fixed externally:

"There can be no such brain-state as the kind of brain-state corresponding to suchand-such a belief in the sense of being a sufficient condition of it. 'Why not?

There are untold millions of possible states of the brain. So it may well be that

\footnotetext{
40 These are published as follows: a) in Faith in a Hard Ground: Essays on Religion, Philosophy and Ethics by G.E.M. Anscombe: 69-83; b) c) and d) in Human Life, Action and Ethics: Essays by G.E.M. Anscombe (Exeter: Imprint Academic 2006) 1-16, 17-25 and 89-108, respectively; and d) in in Roy Abraham Varghese ed. Great Thinkers on Great Questions (Oxford: Oneworld, 1998) 52-6.
} 
among these is a set of states which all are, and which are the totality of, states of a brain whose owner for example believes that such-and-such.' But even on that supposition the brain state is not a sufficient condition for the belief. Why not? Because the belief might be say a belief about banks, and a human being whose brain might get into that state might never have heard of a bank. ... Nor is any other state of the person [a sufficient condition for the belief] ... we cannot ascribe a belief about the bank's opening hours to someone not living in a world of banks and clocks." 41

This sort of argument is more familiar from the writings of Hilary Putnam, Tyler Burge, and Donald Davidson, and Anscombe's presentation combines (or elides) considerations of object (banks) and concept ('a bank') dependence, which Putnam and Burge tended to treat separately as in their examples of "water" and "arthritis". The general idea, however, is clear enough: thoughts cannot be identified with brain states since the character of the latter is fixed independently of questions of intentional content and this depends either conceptually or referentially upon aspects of the subject's environment. As with the Geach temporality proof this is not the occasion to explore the cogency of this externalist, anti-materialist argument. As with the earlier reasoning concerning intensionality I am sympathetic to this type of proof but again there are lines of reply available to the materialist, one of which is to claim that all this shows is that content is not determined intra-cranially and that in so far as thoughts are world-dependent they may be identified with brain-environment complexes. ${ }^{42}$

\footnotetext{
41 "The Causation of Action" 98-9.

${ }^{42}$ For further argumentation see John Haldane "The State and Fate of Contemporary Philosophy of Mind" American Philosophical Quarterly 37 (2000): 301-21. The line of reply I envisage
} 
Elsewhere Anscombe argues differently against materialism. In "The Immortality of the Soul" she reasons that in the case of actions that are explicit expressions of intellectual processes, such as working out a mathematical problem using pen and paper "[while] a purely physical description of this procedure could be given ... that description would not characterize it as thinking or calculating". ${ }^{43}$ At the same time, however, she rejects the idea that what is missing is a description of an internal immaterial activity: "that is not to say it is an act of an immaterial, or spiritual, substance" (ibid.). To the extent that she is willing to allow something to the idea that thinking is 'immaterial' it is only in the negative sense that it is not a material activity. This echoes Geach's observation in "What Do We Think With?" quoted above: "materialism then is false it does not follow that immaterialism [its contradictory] is true" and like him she takes the contrary of materialism to be anti-materialism. ${ }^{44}$

This negative conclusion is liable to prompt questions about what follows positively from the falsity of materialism. Anscombe takes up that issue in "Analytical Philosophy and the Spirituality of Man" which is an uncharacteristically expository essay, perhaps owing to it being the text of a lecture delivered to an audience in Spain that could not be assumed to be familiar

above for the materialist may be countered by claiming that it confuses contingent causal and spatial relations with non-contingent intentional-constitutive ones.

43 "The Immortality of the Soul" 69.

${ }^{44}$ The resemblance between conceptual elements of these two essays, the independent dating of which places them both in the late 1950s, close to the period of the Descartes translations, and the fact that Anscombe's "Immortality" was delivered to the Philosophical Enquiry Group that met at a Dominican venue in England (Spode House) of which Geach was also a member, suggests a degree of mutual influence in these writings, if not 'formal collaboration'. 
with Anglophone philosophy of mind. I suspect, however, that she was also dissatisfied with the earlier essay's negative character; for a close reading of the two texts shows that she had it, or a strong memory of it, before her when writing the latter. Here her anti-materialist argument occurs in the context of expounding Wittgenstein (focusing on Philosophical Investigations Part I, 35 and 36) and placing his views in relation to a familiar three-way distinction between philosophies of mind: Catrtesian dualism; identity-theory, and reductive behaviourism. She writes:

"In describing the options that seem to the present day analytic philosopher to be open for consideration, I have left out Wittgenstein ... Wittgenstein and those who attempt to follow him closely deny that he is a behaviourist . To others the matter perhaps seems to be obscured by a sort of evasiveness: a failure to come out in the open and plump for any one of what seem to be all the alternatives. Does Wittgenstein, do Wittgensteinians, believe that mental events are material events? No. Do they believe they are events taking place in an immaterial substance? Certainly not. Then, if not behaviourism, what do they believe?" 45 Anscombe was familiar with the charge of evasiveness, and with the suspicion that Wittgenstein and perhaps she also were behaviourists, be they of a non-reductive kind; for regarding mind she was a kind of Wittgensteinian, ${ }^{46}$ and closer than Geach to Wittgenstein's

\footnotetext{
45 "Analytical Philosophy" 7.
}

46 This essay is one of the few places where by implication she identifies herself as such. Anthony Kenny reports her as once saying to him "I do not have a thought in my head that does not come from Wittgenstein". He rightly describes this as inaccurate and in her later years she 
own anti-immaterialism. Her argument against materialism begins with reflections on Wittgenstein's remarks about the practice of identifying or drawing attention to some object or feature by to it. Imagine someone doing so and saying "look at this". Nothing in the physical orientation of the body even including the direction of the finger serves to determine the content of the thought including its formal object (whether substance, shape, colour, texture, or location, etc). What makes it the case that a person had in mind the shape rather than the colour, say, is not something passing through consciousness but the context including what was said and done before, and what follows later. Anscombe is concerned to set aside various kinds of reductive interpretations of this account but has little to say about its precise ontological implications.

There are clear connections between this line of argument from ostension and that concerning the impossibility of reducing calculating to the physical process of making marks on a piece of paper. Again, though, the content of the non-materialist account of mind is spare. She writes:

"The immateriality of the soul consists at bottom of the fact that you cannot specify a material character or configuration which is equivalent to truth [or she might have said "to meaning".] ...

We can say that man qua body can't be described as pointing to the colour rather than the shape. For his act of pointing to the colour is certainly a bodily act; but it is not qua bodily act that it is determined as pointing to the colour. This does not mean that we have to postulate a different, another act of pointing by a

once took the opportunity to emphasis in conversation with me that her "greatest teacher" was Frege. 
different sort of substance, an immaterial one - that path to the concept of 'spirit' which Wittgenstein implicitly criticizes. But we can say this bodily act is an act of man qua spirit.

What does it do for us to say this? Is it an explanation? I mean an explanatory hypothesis? No. It might indeed in certain circumstances help to explain the concept of spirit". ${ }^{47}$

It is tempting to say that the view being presented is a kind of hylomorphism where the meaning or intentional content of an action stands to the physical movement (or lack of movement in the most obvious case of a refraining) as form to matter, and then generalizing from this so to say that the relation between a minded agent and her body is that of a substance to its matter. Certainly, like Geach, Anscombe avows an Aristotelian conception of the soul. He writes:

"The only tenable conception of the soul is the Aristotelian conception of the soul as the form, or actual organization, of the living body" 48

While she writes:

"There is a primary principle of the life of any kind of material thing ... This primary principle I call its soul ... The vegetative functions are performed in animal life too. But except for growth they are transposed to a new key. And similarly the remaining vegetative functions and the animal activities and powers

\footnotetext{
${ }^{47}$ Ibid.15-6.

${ }^{48}$ What Do We Think With?" 38.
} 
are transposed in the life of man. For here there is something new: the intellective principle is the differentia of the human soul"49

There being something new does not in itself imply any supervening or emergent immateriality, after all there is something new in the transition from the vegetative to the sensitive functions. Given the foregoing, however, we may grant that she credits to the human kind of life a specific form of non-materiality as indicated by the non-reducibility of calculating to making marks or of intending an object to extending one's finger. But even if the differentia of human life is reason (broadly conceived) Anscombe seems intent on denying that the subject of this is anything other than the living human being, which is a kind of body. She is insistent, and consistent, in resisting any reifying inclination to interpret the idea of an intellectual principle as an intellectual subject unto itself; and there is nothing like Geach's concession to the possibility of "disembodied thought; thought unconnected with any living organism". She even writes in a way that might seem directed against the sort of thing that Geach had proposed. Immediately following the previously quoted sentence he wrote "And some continuing disembodied thought might have such connexion with the thoughts I have as a living man as to constitute my survival as a 'separated soul'. To be sure, such survival must sound a meagre and unsatisfying thing ... Even if Christians believe there are 'separate soul', the Christian hope is the glorious resurrection of the body, not the survival of a 'separated soul'. Meanwhile she wrote "there is no reason whatever for believing in a temporal immortality of the soul apart from the resurrection; above all there is no 'natural immortality of the soul' that can be demonstrated by philosophy ... I take the Christian doctrine of

\footnotetext{
49 "Has Mankind one Soul?" in Human Life, Action and Ethics: Essays by G.E.M. Anscombe op. cit., $18 \& 22$.
} 
immortality to be the doctrine of an unending human life, happy or unhappy, after the resurrection and not the doctrine of an immortal sort of substance, the soul, to which is appended the doctrine of the resurrection because a disembodied soul is not a complete man, though I know that in apologetics the matter is often presented like that". ${ }^{50}$

One might make the case that the issue is one of emphasis, and cite in support of this that Anscombe seemingly allows the same possibility as Geach envisages when she writes elsewhere "If the principle of rational human life in E.A. is a soul (which perhaps can survive E.A., perhaps again animate E.A.) that is not the reference of 'I'. Nor is it what I am. I am E.A. and shall exist only as long as E.A. exists" ${ }^{51}$ Her "perhaps" may correspond to his concession introduced by the phrase "there is a logically open possibility". My sense, though, is that her skepticism or resistance was the stronger and I offer a final piece of evidence in support of this assessment. Presented with the observation that Aquinas held that the spiritual, i.e. immaterial, nature of the human was grounds for affirming the possibility of it surviving death she replied "Well, he investigated it. It was for him a serious problem precisely because he believed the Aristotelian principle - the soul is the form of the body.... Probably he did [think this]. I would say to him it was a problem and it is not clear that he solved the problem. I don't think I know his writings well enough to say, but I

50 "The Immortality of the Soul" 77.

51 "The First Person" op. cit., 35. Kripke points out that her use of her initials "E.A.” to distinguish "I" from a genuine referring expression follows Wittgenstein's use of "L.W" nin a similar contexts, and that in Mental Acts Geach does likewise, distinguishing "I" and "P.T.G."; see Kripke "The First Person" op. cit., 311. 
would expect that he thought he had solved the problem. What I do note is that for him it was a problem and that is the right approach to this matter which should be a problem." 52

Anscombe knew Aquinas's writings pretty well and I think that here she is being charitable not wanting to say that Aquinas believed he had given a coherent account of how the form of the body may also be a subsistent that can survive the death of the body, because she thought that if had believed that then he would be in error.

Geach wrote "we think about different though overlapping topics, and in a noticeably different style; and either of us, when questioned about the thought of the other, will often not know the right answer". Here we have seen them thinking about closely aligned topics and in ways that suggest a fair degree of familiarity with what each had written. There are differences of style, but also of emphasis and perhaps of substance. They both believed that materialism is false and argued against it; but Geach's arguments are more directly and obviously metaphysical in manner and implication. Both deny that human beings think with immaterial parts of themselves (their souls), but Anscombe also labours to distinguish sharply between immateriality and spirituality, not just with respect to substance but with respect to activities. For her the 'spirituality' of the human being is not a matter of some immaterial ontological component but is shown most clearly in the human orientation towards value. Men are drawn towards truth, towards the good, and towards the eternal, not just as formal objects of speculative and practical thought but as ends (finisis) of life, which not being naturally attainable stand as transcendental ends that might yet be given - by God, in the life of the world to come. That, however, for Anscombe and Geach, is the resurrected world.

\footnotetext{
52 "The Existence of the Soul" $53 \& 55$.
} 
What then to make, philosophically, of their rejection of materialism and of immaterialism (save than in the sense in which the latter is equivalent to non-materialism). As regards the former I have expressed appreciation of their arguments, and while acknowledging likely directions of reply, particularly on behalf of token physicalism, I think there are further grounds for rejecting both reductive and non-reductive materialism, and that the envisaged lines of response can themselves be countered. One set of such grounds are those appealed to by Aquinas in his arguments for the immateriality of intellectual acts which I will consider in a moment.

First, however, there is the issue of Anscombe's and Geach's skepticism regarding, or rejection of, the idea of an immaterial subject of thought such as might continue following the death and destruction of the human body. Geach's concerns are clearly set out in Mental Acts, and in God and the Soul. They are of two sorts. First, that concepts of mental events, processes and dispositions such as seeing, hearing, being in pain, being angry, having a belief or a desire and so on, apply primarily to human beings, and in some cases by extension to other animals; but that we can make no sense of applying them to an immaterial subject. The contents of these concepts are acquired and given through language, and the application of the associated terms is non-contingently linked to features of the natural environment, to conditions pertaining to that and our interactions with it, and to the behavior of those whom such mental events, processes and dispositions are predicated.

Disconnecting the use of psychological terms and concepts from these physical and bodily ones drains away the sense of the former. The conditions necessary for ascribing 'seeing' to a subject involve a) the presumption of visual experiences, but also certain kinds of behavior 
such as focusing and responding, b) the visibility of the objects seen which is in turn connected with various physical features of subject and object, such as the conditions of the eyes, and c) the causal links between these and perceived objects (and further enabling conditions). Remove b) and c) and it is no longer clear that one can coherently ascribe 'seeing' or hold on to the idea of visual experiences.

The second set of concerns relate to the identity or continuity of a disembodied subject with a previously existing human being, and to the individuality of an immaterial entity. The issues are the familiar ones of personal identity and individuation. Sameness or difference in respect of characteristics do not constitute the individuality, continuity or identity of a substance but presuppose them. In the case of physical substances being one, and being the same involve quantities of designated matter (materia signata quantitate), but on the hypothesis under consideration there is no such matter.

Geach's overall assessment of these two kinds of considerations is that the first rules out as unintelligible the idea of sentient immateriality while the second implies the impossibility of what I will term 'intrinsic' individuality and identity. Consistent with his reluctatnt concession to the idea of a separated soul, however, he introduces the possibility that while such an entity could not be a subject of experience it might be identifiable extrinsically, or relationally, via its historic and prospective (via resurrection) connection to living human bodies. He writes: "So the upshot of our whole argument is that unless a man comes to life again by resurrection, he does not live again after death. At best some mental remnant of him would survive death; and I should hold that the possibility even of such survival involves at least a permanent capacity for renewed human life...".53

\footnotetext{
${ }^{53}$ Geach "Immortality" God and the Soul, 28.
} 
Returning to Anscombe I find two arguments directed against the idea of an immaterial subject of human thought both of which relate to the idea of substance. The first is explanatory and debunking of considerations taken to favour postulating an immaterial subject; the second challenges the coherence of the very idea of such. The former restates reasoning by Wittgenstein expounded in "Analytical Philosophy and the Spirituality of Man". Here it will be useful, therefore, to have those original passages before us.

"To repeat: in certain cases, especially when one points 'to the shape' or 'to the number' there are characteristic experiences and ways of pointing 'characteristic' because they recur often (not always) when shape or number are 'meant'. But do you also know of an experience characteristic of pointing to a piece in a game as a piece in a game? All the same one can say: "I mean that this piece is called the 'king', not this particular bit of wood I am pointing to".

36. And we do here what we do in a host of similar cases: because we cannot specify any one bodily action which we call pointing to the shape (as opposed, for example, to the colour), we say that a spiritual [mental, intellectual] activity corresponds to these words. Where our language suggests a body and there is none: there, we should like to say, is a spirit." ${ }^{, 54}$

In brief, the argument is that while an intentional action (expressive of, or manifesting, a mental state) cannot be identified with a physical movement or, importing the earlier externalist conclusion, with movement plus some associated brain states, it is a mistake to move from the non-materiality of action in this sense to the idea that it derives from a 'spiritual' activity and

\footnotetext{
${ }^{54}$ Ludwig Wittgenstein, Philosophical Investigations, trans. G.E.M. Anscombe (Oxford: Blackwell, 1953) Part I. 35 \& 36.
} 
thereby to conclude that the agent is some immaterial entity associated with the body. The explanation of what encourages this move involves the (misleading) grammar of ascription, and in showing that no such inferences are warranted the analysis thereby also debunks the idea that non-materiality implies immateriality of activity and thereby of agent.

There are, I think, two main things to be said about this. First, while there may appear to be an ontological leap in moving from the non-materiality of an activity to the immateriality of the actor, it is not obvious that such a leap is involved in proceeding from the immateriality of an act to that of the agent. Of course, if by 'an immaterial act' one simply meant 'act of an immaterial agent' this would invite the charge of petitio principii. But this need not be definitional. Anscombe thinks that the considerations she endorses only tell against materialism but not in favour of immaterialism, but this assumes a distinction between the falsity of the former and the truth of the latter. If anti-materialism is simply a negative claim then that may be the case, but only if 'non-materialism' with respect to an activity can be given determinate content short of immaterialism regarding it. Put another way, if anti-materialism is nonmaterialism, and this is more than say a claim about incommensurable descriptions of one and the same thing, then it looks as if the least that Anscombe is committed to is property dualism and that seems to amount to immaterialism regarding attributes, ie., to the claim that there are real non-material features. Alternatively, if she would deny this then it is hard to see that her non-materialism amounts to an ontological position rather than a form of conceptual pluralism.

At the outset of “Analytical Philosophy" Anscombe writes "I can't help thinking that the Platonic substance, the Idea or Form, is of importance in the tradition whereby intellect came to be thought of as immaterial substance. For that which could grasp those immaterial beings the 
Forms, had itself to be immaterial: the soul, Plato said is akin to the Forms". ${ }^{55}$ Then in conclusion she returns to this idea now seeming to endorse it: “... the pre-Cartesian, indeed originally Platonic conception is right.... The immateriality of the soul consists at bottom in the fact that you cannot specify a material character or configuration which is equivalent to truth" 56 It is unclear how close to equivalent Anscombe takes the affinity of thought to the forms and to truth to be, though one might suppose that the reasoning is that in both cases the objects of thought are immaterial and that whatever can 'grasp' either must share that nature. But the conclusion mentioned in each case concerns not just thinking but the thinker, and this raises a question about how to reconcile Anscombe's sympathy to these Platonic views with her antipathy to the idea of an immaterial soul.

A cluster of object-act affinity arguments is to be found in Aquinas, most pertinently that which reasons from the nature of the contents of intellectual cognition which are universals rather than particulars and hence exist apart from matter ${ }^{57}$ : but he is also explicit in providing the further act-agent link. In his Commentary on Aristotle's De Anima he writes:

"The type of every act or operation is determined by an object. Every operation of the soul is the act of a potentiality, either active or passive. ... The objects of the active capacities are related to these as the final terms attained by the activities; for in this case the object is what each of these activities effectively realises.... The objects in question are such things as sensible being and intelligible being

\footnotetext{
${ }^{55}$ Op. cit., 4.

${ }^{56}$ Op. cit., 15.

${ }^{57}$ See Summa Theologiae Ia, 75, 5.
} 
with respect to the sensitive and intellectual faculties. ... So we proceed from objects to acts, from acts to faculties, and from faculties to essence." 58

The character of the argument is clear enough: the cognitive objects of intellectual acts are immaterial forms; acts are specified by their objects, hence intellectual acts are themselves immaterial; but faculties are specified by acts, hence immaterial faculties; and the bearers of faculties are specified by the nature of the faculties, hence immaterial subjects. ${ }^{59}$ Another way of approaching the same conclusion is by thinking about the attribute-bearer relation and the plausibility of a metaphysical compatibility principle to the effect that a fundamental attribute of kind $\mathrm{K}$ can only be possessed by a bearer of kind $\mathrm{K}$. This would explain why an immaterial bearer could not have material properties, and by parity of application why a material bearer could not have immaterial ones.

Such considerations, in conjunction with earlier argumentation, favour the idea that there is an immaterial subject of thought. But still standing against this is Anscombe's second argument which challenges the coherence of an immaterial substance. Her claim is that the very notion is a delusive conception. The argument is somewhat obscure but it is connected with the fact that substance concepts are introduced in answer to certain kinds of 'what' question; specifically those that ask 'what is the nature of that (thing)?' and are answered by specifying

${ }^{58}$ Aquinas, Commentary on Aristotle's De Anima trans. Kenelm Foster O.P., and Silvesteer Humphries O.P. (London: Routledge \& Kegan Paul, 1951) Book II, Lectio six, 208-9.

${ }^{59}$ For further discussion see John Haldane "Kenny and Aquinas on the Metaphysics of Mind" in John Cottingham and Peter Hacker eds. Mind, Method and Morality (Oxford: Oxford University Press, 2010) and "Is the soul the form of the body?" American Catholic Philosophical Quarterly, 87, (2013). 
what the nature or whatness is - quod quid est (hence quidditas, 'what-it-is-ness'). Her point, if I understand it, is that whereas such questions are in order so far as natural (material) substances are concerned they lapse, or fail to find application, or make no sense in connection with the idea of immaterial substance. Perhaps another way to put the point would be to say that there are no such natures as those of kinds of immaterial entities, no 'whatnesses' of them.

This deserves an extensive discussion in place of which I can only offer a series of brief observations serving as headings for further enquiries. First, and following Aquinas we might note that the nature of a thing may be specified from its powers, as indicated by its acts, as specified by their objects. Arguably such a procedure lies behind the formulation of concepts of natural substances but in the case of the agent of intellectual activities it might be granted that since only its operations and effects are cognisable, notions of what-it-is are somewhat obscure. Second, and connected to this is the thought, again advanced by Aquinas, that the intellectual soul as agent of thought is not directly apprehended even in the consciousness of one whose soul it is but is only ever inferred. ${ }^{60}$ Third, such a scheme ought to be familiar from another case of a seemingly ineffable subject, namely God. In Summa Theologae Ia q 2 considering whether the existence of God can be demonstrated Aquinas notes that inferences may proceed either a priori from cause to effect or else a posteriori from effect to cause, and explains that where a cause is not directly known it may yet be inferred from observed effects as a necessary condition of them. As in the case of a transcendent immaterial cause, so perhaps in that of an immanent one. Again in questions 4 and 13, and elsewhere as in De Potentia VII, 5 Aquinas advances the idea of

60 The fact that there may be no introspective awareness of the subject of one's mental acts should be distinguished from whether there is reflexive knowledge of such acts. On the latter see John Haldane “(I am) Thinking” Ratio 16 (2003) 124-39. 
primary and secondary applications of concepts to creatures and to God, which one may take as an instance of a more general pattern of analogical predication that might be invoked in the case of the agent of intellectual acts. In the case of affirmative (via analogica) predications he observes that because of the different mode of signification of terms applied to creatures and to God "the affirmation of them is described as vague as being not altogether fitting". Again one may suppose something similar in the transfer of descriptions of the effects of mental activity such as speech, to the source of it.

In relation to the terms 'makes' and 'made' as applied ordinarily to the work of cooks or sculptors whose making consists in modifying some pre-existing stuff, and extraordinarily to the creative activity of God ex nihilo, Anscombe writes "as soon as 'out of nothing' is introduced we are using 'makes' in a new way, which paralyses critical questions based on the implications of the former way: but the fact that it is a new way is not itself a criticism; it would not be possible to erect a principle of never using words in a new way without paralysing language." 61

This observation comes, however, just a few pages after writing about the delusiveness of the conception of an immaterial substance. My sense is that she was not willing to grant to the latter the same scope for innovation and development and that the reason for this was less a convincing case against the possibility of a separable intellectual subject 'the soul', than a conviction that any philosophical argument for such a thing had been scuppered by Wittgenstein and any religious concern for future life was fully met by the hope of bodily resurrection. Geach thought the latter too but he was willing to concede more to the immaterialist possibility not for want of appreciation of Wittgenstein's arguments against Cartesianism but in recognition that what Aquinas argued for was something sparer. I think a coherent possibility lies thereabouts and

\footnotetext{
61 “Immortality", op. cit., 70.
} 
that he case for it begins with arguments against materialism including those advanced by Anscombe and Geach, but I am happy to accept that until much more work has been done an appropriate attitude might be one of agnosticism certainly with regard to the whatness, if not so certaintly to the thatness of the human intellectual soul.

Baylor University, Texas

St Andrews University, Scotland. 